\title{
Selvmordsforbygging i Buskerud: fra idé til prosjekt
}

Roger Simonsen intervjues av Dag W illy Tallaksen

\section{B uskerud betraktet enkelte sitt hjemfylke som en "versting" i klassen av fylker med} behandlingskjedeprosjekter. M ed et mislykket forsøksprosjekt som bakgrunn var oddsene for suksess heller dårlige da et nytt prosjekt ble påbegynt i 1998. M en høgskolelærer Roger Simonsen ved $\mathrm{H}$ øgskolen i Buskerud ( $\mathrm{H}$ iBu) ville noe annet.

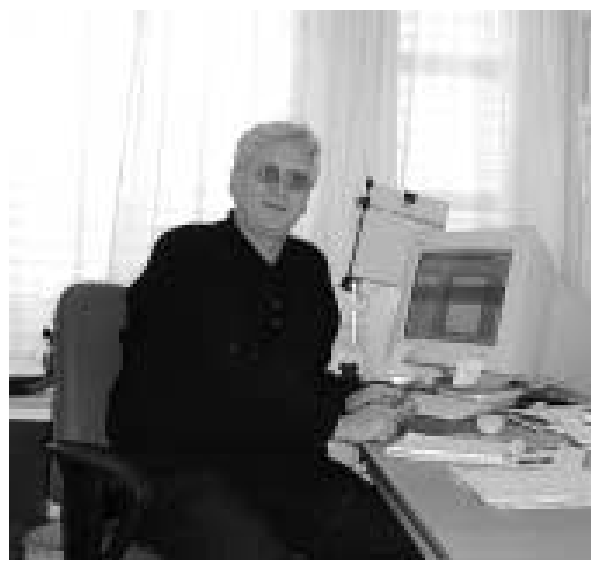

Tidsskriftets utsendte medarbeider møter en lettet og glad Simonsen på hans kontor i Drammen tidlig i januar 2001. M øtet finner sted i god tid etter at siste brikke er falt på plass i prosjektets startfase. Fra november 2000 har samtlige sykehus og kommuner vært inkludert i "Prosjekt:

Tiltak mot selvmord - Buskerud. "Behandlingskjede betyr i denne sammenheng at alle personer som kommer i kontakt med lokalsykehuset etter et selvmordsforsøk, skal være sikret en viss standard i oppfølging fra institusjon og primærkommune. $M$ ålet er at ingen skal overlates til seg selv før de har fătt tilbud om oppfølging. $M$ ed dette har Buskerud fått en god start i henhold til oppfølgingsprosjektet "Tiltak mot selvmord" (Statens helsetilsyn), der det i punkt 5.4 sies at det skal sikres "gode oppfølgingsrutiner for mennesker i selvmordskrise."

\section{H vordan kom du i gang med dette arbeidet?}

- Selvmord og selvmordstruede mennesker har opptatt meg i lengre tid. J eg har møtt selvmord i faglig og privat sammenheng, og ser at her er mye ugjort. Ved hjelp av midler fra Statens helsetilsyn ble det mulig å gå inn i fagfel tet som prosjektleder, riktignok i vekslende stillingsstørrelser. Selve prosjektet startet med etablering av styringsgruppe. Ettersom tidspunkt for oppstart nærmet seg, ble det også avholdt et informasjonsmøte ved
$\mathrm{H}$ iBu der mange faggrupper og miljøer var representert. BI. a. var professor dr. med. N ils R etterstøl var en av foreleserne. Dette ga prosjektet positiv og god blest i de berørte fagmiljøene. Deretter tok jeg i bruk min lokal kunnskap og kjennskap til sentrale personer som jeg antok ville være motivert for å delta i prosjektet. Det ligger mye reisevirksomhet og personlig kontakt bak det som i dag er et fylkesdekkende tiltak.

\section{H vilke andre suksessfaktorer ligger i bunn av prosjektet?}

- Det viktigste er nok at vi tidlig laget en prosjektskisse hvor vi formulerte klare og avgrensede mål. Vi innså, og tok konsekvensen av, at alle som skulle delta i prosjektet ikke betraktet dette som sitt viktigste anliggende i det dagl ige arbeidet. Videre har det vært avgjørende med lokal forankring. Det har vi lagt vekt på når vi i dag har prosjektet gående som et samarbeid med Felles helse og sosial plan i Buskerud. Forut for oppstart ved hvert av de tre sykehusene har det blitt lagt vekt på god dialog med de impliserte parter. A lle koordinatorer i sykehus, representanter for primærkommuner og tilsynspsykiater har del tatt i samarbeidsmøter. Det er gjennomført internundervisning for at alle skal ha kjennskap til de sentrale idéene i tiltakskjeden. Forut for oppstart ble alle involverte invitert til å delta på Vivatkurset " Førstehjelp ved selvmordsfare". Kursdeltakelsen var uten kostnad for den enkelte. Faglig har prosjektet hele tiden vært knyttet opp mot DPS i

Drammen, og er det fortsatt selv om hele fylket nå er inkludert.

\section{En svært viktig faktor er nok at}

Simonsen har tatt aktivt i bruk sitt kontaktnett i fylket. A rene som lærer ved $\mathrm{HiBu}$ har gitt godt innsyn i sykehusene og kommunene i Buskerud. Kollegene ved $\mathrm{H}$ øgskolen har også uttrykt stor forståelse for prosjektet og gitt verdifull støtte underveis.

\section{Prosjektet startet i D rammen og N edre E iker. H vorfor?}

- Siden prosjektet er faglig forankret ved D rammen D PS var det naturlig å konsentrere innsatsen i nærområdet. Vi ønsket å starte med et omfang på tiltaket som vi kjente oss komfortable med. Det hele ble etablert som et samarbeid mellom Buskerud Sentral sykehus (BSS) og kommunene Drammen og $N$ edre Eiker. Først når prosjektet var i god gang ved BSS og rutiner var innarbeidet, ble det aktuelt å videreføre prosjektet til hele fylket. I dag finnes det kontaktpersoner ved alle aktuelle sykehusavdelinger og i alle primærkommuner. Det er også etablert rutiner for å erstatte personer som går ut av prosjektet ved for eksempel permisjon og oppsigel se. Dette er en liten, men viktig detalj for å sikre fremtiden .

\section{H vilke andre tanker har du gjort deg om prosjektets fremtid?}

- Ø konomien blir avgjørende. Det ønskelige er at det i fylkeskommunen finnes en prosjektleder som kan følge opp og videreutvikle det som nå er påbegynt. H ver gang en medarbeider slutter, må det nye inn. Det vil derfor være et kontinuerlig behov for fagutvikling og undervisning. Skjemaene som i dag benyttes, må evalueres og evt. endres. A llerede nå ligger det en betydelig mengde data i disse, som bare venter på en interessert forsker. Det må heller ikke bli slik at dette fungerer som en sovepute for psykiatrien.

Simonsen ønsker seg en koordinator ved Lier sykehus, slik at pasientene der også kan dra nytte av de ressurser som nå etableres i nærmiljøene. $\mathrm{H}$ an ønsker seg at det sammen med koordinatoren i hver kommune etter hvert skal kunne utvikles et lavterskeltilbud for mennesker i selvmordskrise.

Det betyr at vi må finne ressurser til opplæring og markedsføring av tilbudet. - Det er nok å ta fatt på i det videre arbeidet, sier Simonsen. 